\title{
Socio-economic and Geo-political Transitions in the Mediterranean Basin and Its Impact on Urban Forms of Port Cities
}

\author{
Husam R. Husain ${ }^{1, *}$, Hassina $\mathrm{Nafa}^{2}$ \\ ${ }^{1}$ Architecture and Urban Design Program, German University in Cairo, Cairo, Egypt \\ ${ }^{2}$ Department of Architecture, Girne American University, Girne, N. Cyprus
}

Received July 22, 2020; Revised August 12, 2020; Accepted August 20, 2020

\section{Cite This Paper in the following Citation Styles}

(a): [1] Husam R. Husain, Hassina Nafa, "Socio-economic and Geo-political Transitions in the Mediterranean Basin and Its Impact on Urban Forms of Port Cities," Civil Engineering and Architecture, Vol. 8, No. 5, pp. 898 - 907, 2020. DOI: 10.13189/cea.2020.080517.

(b): Husam R. Husain, Hassina Nafa (2020). Socio-economic and Geo-political Transitions in the Mediterranean Basin and Its Impact on Urban Forms of Port Cities. Civil Engineering and Architecture, 8(5), 898 - 907. DOI: 10.13189/cea.2020.080517.

Copyright $\mathrm{C} 2020$ by authors, all rights reserved. Authors agree that this article remains permanently open access under the terms of the Creative Commons Attribution License 4.0 International License

\begin{abstract}
In the last decades, the Mediterranean region is experiencing economic, social, and spatial changes in its structures. Today, cities are experiencing an increasing number of complex problems regarding internal and external connections, reflecting on the city structural realm. The physical transformation of territories in general and cities in particular are associated with external trends, such as migration, post-colonization affects, social changes, economic, and political activities. The paper concludes how coastlines act as an interface between internal and external transitions of the Mediterranean region, and highlights those territories as important defensive lines which could embrace the Mediterranean challenges. The attitude of coastlines as a system basis of cities can find a compelling rationale as well as a cohesive meaning of recovering its major role in embracing complex external and internal relations, which result in the formation of a strong and coherent urban system to cope with constant transitions of the region.
\end{abstract}

Keywords Urban Evolution, Transformation, Urban Trends, Mediterranean Region

\section{Introduction}

The location of the Mediterranean Sea has always been a transitional hub of economy and culture, which played a prime role in increasing the rates of population and urbanization in the Urban Mediterranean region. The economic and governor status of the region made it clear that the proportion between the rate of population and growth of cities is in direct relation to the urban history and the location of cities on the world map. In the 21 st century, the socio-economic and geo-political experiences are constantly transforming the physical spatial structure of cities, whereas their images are being seen within a wider lens; a perspective that consists of internal local transitions, and external influences and forces which shape their structure.

The social transformation of the Mediterranean region in the last decades has given a prime significance to the coastal cities over hinterlands due to their geographic location as a transitional hub and a major link between hinterlands and linear coastal connections of a particular Mediterranean strip, especially that these cities became a prime destination for people migrating because of several social, economic and political concerns.

Subsequently, the world is about to enter a post urban era, where cities do not anymore indicate their own local significance, instead; they become sub-structures within a wider regional and territorial transformation parameter. This territorial structure is characterized by the relation and the connection between cities and regions, rather than a 
case-by-case cities' transitional factor. In view of that, this study suggests that the Mediterranean coast is a common analytical element within a larger frame represented by the connections between different Mediterranean regions.

\section{Urban Transformation Drivers}

In the 19th century, ports construction was undertaken in great cities in the hope to cope with the industrial boom, while small cities where still in the need to moderate their infrastructure and facilities. Consequently, the economic activities were reoriented towards the coast and hence the external world. Therefore, the construction of ports around the Mediterranean fostered the transformation of the physical structures of port cities, and led to raise new social and economic trends with it. The projection of these activities can be seen in the form of physical transformation in the urban structure of cities [1].

With the advent of the third millennium, the population of cities has surpassed the rural, with over than 50 percent of the world's population living in urban areas [2]. Today, with the increasing urban challenges related to global socio-economic and geo-political statuses, many cities and towns are experiencing an increasing number of complex problems regarding internal relationships and external connections. These problems are uprising from wars, colonization, and urbanization, thus rapid transitions in structural realm of cities are being witnessed over the last two decades.

Globalization, which produces major international networks between different territories, opened the door for new urban regional delineation to fulfill the development needs of cities around the world, particularly with the centralization strategies of great cities, which places great responsibilities on governments and local institutes.

The global urban concentration in the late 20th century was typically on cities with significant population and regional spatiality, whereas little towns (in terms of the number of inhabitants) have been neglected in spite of their role in the transformation process between major cities, besides their important role they played being transitional bridges between the coast and hinterlands. However, the importance of these towns has arisen significance to face the urban challenges of the $21 \mathrm{st}$ century, mainly the interfaces of the Mediterranean coastal zones.

\section{Urban Transformations of Ports Dynamics}

The industrial revolution in the 18th and 19th centuries produced the greatest transition in human history $[2,3]$. This transition is remarkable through an effective separation between work, study, and residence. Natural growth in both urban and rural areas has begun to lose its prestige due to the growing desire to cope with the growing pace of population and urban demands, as well as the desire to follow up with the industrial production around the world. This has resulted in unequal local population distribution between urban and rural areas, whereas the global up-growing industrial trends in the last decades re-shaped the urban distribution amongst cities.

\section{Materials and Methods}

Many cities centered on the Mediterranean Sea had varying influence roles in the form of the general economy of the entire region through its strategic location that dominated global trading routes in the past, and other social and political factors at the present time. These cities took advantage of their position to develop future strategies by partially or completely transforming their infrastructure, which leads to changing the city's shape and its main function to provide equal economic and social opportunities for its residents. The selected case studies are Limassol and Famagusta in Cyprus, Corinth in Greece and Beirut in Lebanon. According to their different locations, these cities represent varying compositions within the Mediterranean region; Famagusta, Limassol, and Beirut are on the continuous coast of the Mediterranean, whilst Corinth and Isthmia are connected via the Corinth Canal to the Mediterranean Sea. Therefore, two models were analyzed to coherently conduct the study of the region mainly the coastal and the artificial link. Further, these cities present a comprehensive view of the Mediterranean region from their strategic locations which represent a holistic overview of socio-economic and geo-political factors that are affecting these cities positively or negatively over time.

\subsection{Positioning and Economic Parameters}

The city of Limassol in Cyprus is an explicit example of the impact of global economic and territorial social transitions on coastal cities. In 1979, the expansion of the city began to flourish and the increase overtook the neighbouring villages. After the construction of the new port in 1937, the economic activities of the old port which was considered the largest on the Mediterranean trade lines began to decline rapidly. Therefore, major changes occurred in the infrastructure, because the old port, which was located in an important historical centre, lost its economic and social role that was considered the main transportation and economic centre for the region as a whole. The old economic centre did not only have commercial and cultural significance, it also acted as a social disseminator. The lower social classes of the population lived in the southern part of the city around the port, working in harbour related activities, while the 
wealthier class lived in the north and in the centre, where Limassol's coast was mostly shops, and some residential areas in the West and warehouses in the East. However, with the considerable increasing rate of touristic activities over the past 25 years, a noticeable change occurred on the waterfront in relation to both land use and residential buildings' typologies. Therefore, the wealthy class started to trace over low social classes' lands, hence the whole coastline is today fully occupied with new projects which consist of shops, recreational areas, and middle and high-residential buildings [4].

The strategic location of the city, facing African, Asian, and European Mediterranean coastlines, acted as a major factor in the emergence of port-city notion in relation to the external world. This has directly affected the formation of the city spatially and functionally. Therefore, due to the regional central focus it played overtime, Limassol was a factor for both the thriving and further development of the new port. In 2017, it further expanded by constructing a new cruise terminal to accommodate the largest cruise vessels. The port's development doesn't seem to be stopping in the near future but rather prospering [5].

The previous changes that occurred in the port of Limassol were one of the factors that affect changing the shape and functions of the coast, hence the city. The city today extends from east to west further than $15 \mathrm{~km}$ along the coast with the newly developed corridors and parks. Nonetheless, following the industrial and commercial activities along the coast, the distribution of land-use has a major influence on the shape of the city. Poor and massive coastal developments have caused problems such as coastal erosion due to slow government measures to provide solutions, therefore citizens tend to resort to illegal solutions such as vertical wave barriers created in the hope to improve and protect beaches. As a result, the physical network of Limassol gives a comprehensive overview on the morphological transitions of the city, with multiple urban fabrics nowadays as shown in Figure 1 below.

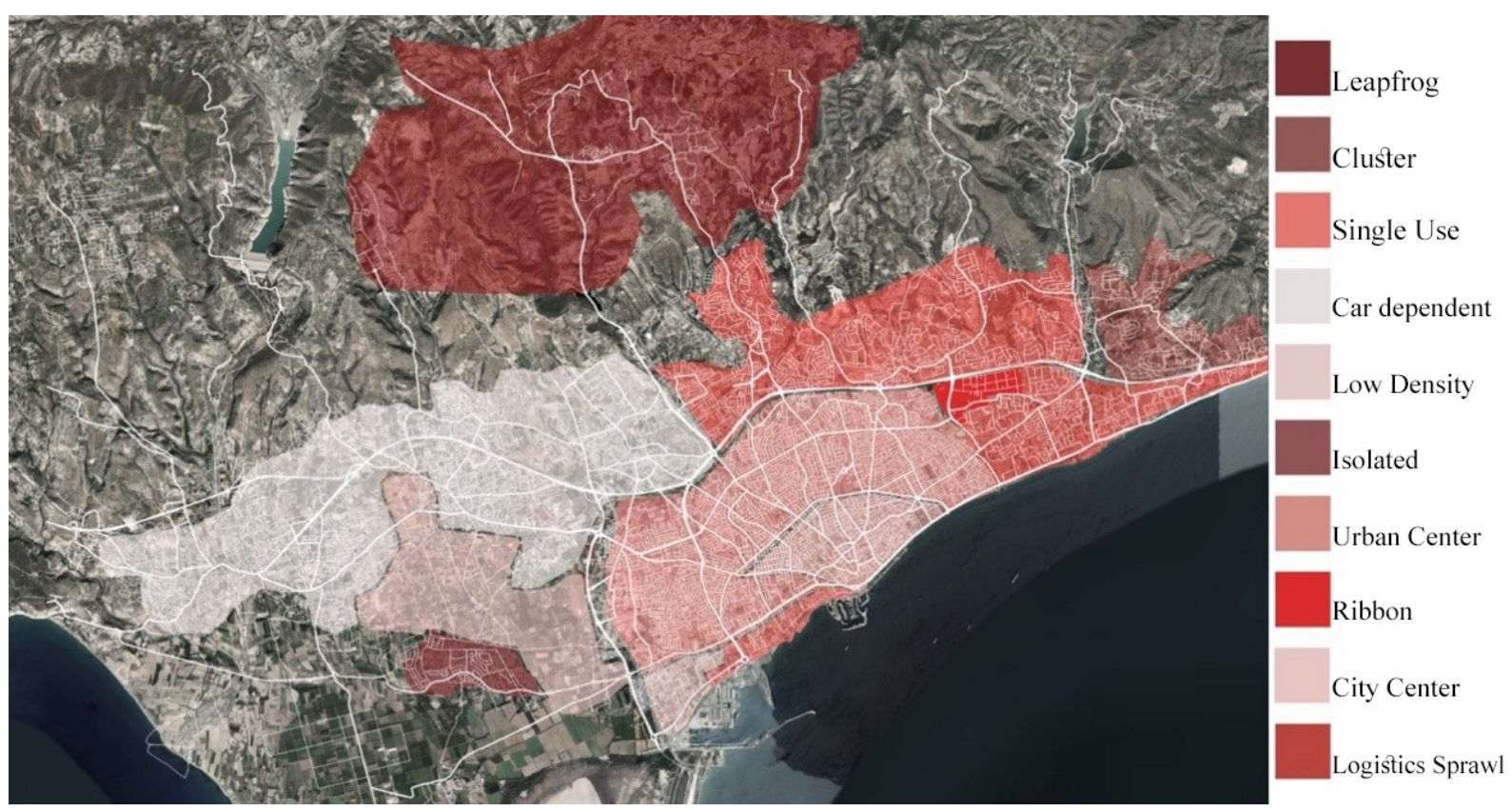

Figure 1. Different fabrics present in Limassol 
"Previous spatial analyses of Limassol's growth have pointed out that uncontrolled urban development led to an uneven expansion of the city, creating a fragmented structure and leaving many gaps in the urban fabric" [6].

The main drivers of the growth in the city are represented by the radial network which connects the Eastern side of the coast to the western side. The formation of this network was based on the central historic core. The hierarchy of the network is presented by main roads perpendicular to the coastline and radial roads around the old port with organic secondary streets in the parcels created in-between. Furthermore, the fabric of the city around the coastline indicates that the densest urban area of the city is located directly above the old port where the city first emerged. This gives an insight of the importance of the historic centre and the old port, which was dominating the central coastal zone of the city.

The exact opposite of the case of Limassol, on the northern Mediterranean Sea bank where Greece is located, the city of Corinth suffered from severe collusion in the population and urban growth after the construction of the Corinth Canal. After the earthquake in 1858 resulting in the destruction of what is now called Ancient Corinth, The Municipal General Plan of the same year was developed over the vision of building a new city around a small harbour. The strategic location of the city on the Isthmus region that connects the Gulf of Corinth with the Mediterranean Sea promised economic success along with a port that will open up new commercial opportunities. However, the economic significance of the newly built city indicates a lot less than it used be in the ancient era [7].

Corinth location on the coastline of the Gulf of Corinth and its port being close to the Corinth Canal entrance might have promised economic success to the city; however, according to Mambra [8], once the canal was constructed, it was not economically successful as expected earlier; It was difficult to navigate through the canal due to its narrowness and the frequent high winds and strong currents. Another reason that hindered the success of the canal is being located in an area of high seismicity. High seismicity in the nearby area of the Corinth Canal caused slope instabilities especially at the sites of the slopes that are characterized with low safety factor [9].

Therefore, this determines two important factors in the development of cities in the post-industrial era; first building ports for economic and political purposes, and exploitation of the location. However, visions differ, and misuse of geographical features may lead to urban disasters, as witnessed in the case of Corinth.

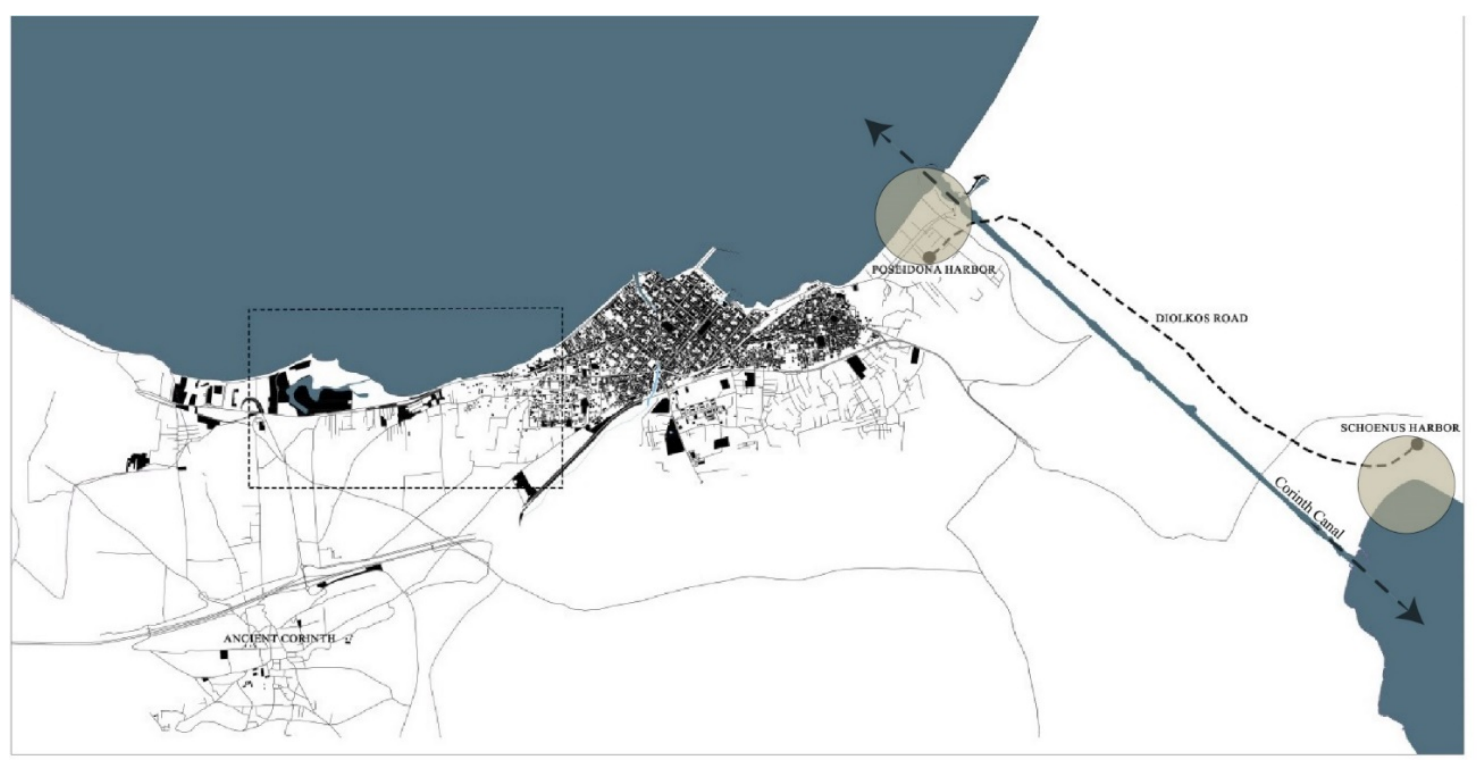

Figure 2. Influencial economic elements impacting on the Corinth region 


\subsection{Geopolitical Transitions and Their Impact on Social Solidarity}

The average population density in coastal areas is about 80 persons per square kilometre, twice the world's average population density [10]. Kostof [11] acclaimed that clean running water is the most critical aspect for human settlements, for example, around the Nile River; the density is in the average of 750 people per kilometre square. Therefore, the social aspect and the geographical context play a major role in the urban development of the coastal areas. Subsequently, investments in infrastructure increase with the growing demand, hence the need for better urban qualities triggers. This process of regeneration and expansion differs from a place to another, resulting in the formation of various new urban patterns.

The dislocation between coastal cities and hinterlands does not only have an economic, social and geographical dimensions, it has also increased physical independency from one city to another. In the last decades, cities became more connected socially and hence physically due to immigration and multiple social factors. The morphologies for the origins of urbanism are not limited to the local internal distribution of population within cities, rather, they also include several multidimensional aspects such as the military actions, political forces and sociological human responses with religious reasons, which led to more infrastructure needs through a heavy bureaucracy [11].

The city of Famagusta in the southern east coast of Cyprus is one of the most prominent examples in the Mediterranean Sea which reflects a major physical transition due to external socio-political factors. The city developed from ancient times near the coast, where it was known mainly for fishing as well as being an important trading hub. The growth of the city was affected after the division of the island of Cyprus (Figure 3). As the growth of the city was shaken by the establishment of military areas along the coast, these changes occurred in the city's early form, and as a result, it has shifted from an economically self-contained village to a more complex structure of social and political dynamics.

Therefore, a dramatic transition in Famagusta's urban realm occurred due to the geo-political role responding to the socio-economic needs of the Mediterranean region. The city, which was originally founded as a small fishing town around $300 \mathrm{BC}$, and later became an important commercial coast, suffered from the incident that marks the beginning of the spatial separation between Greek and Turkish Cypriots. Since then, Famagusta has lost its significance as a coastal city, and the importance of the city has shifted to be a response to migration beginning in 1986 when the University of the Eastern Mediterranean was founded, which led to massive unplanned urban growth (Figure 4).
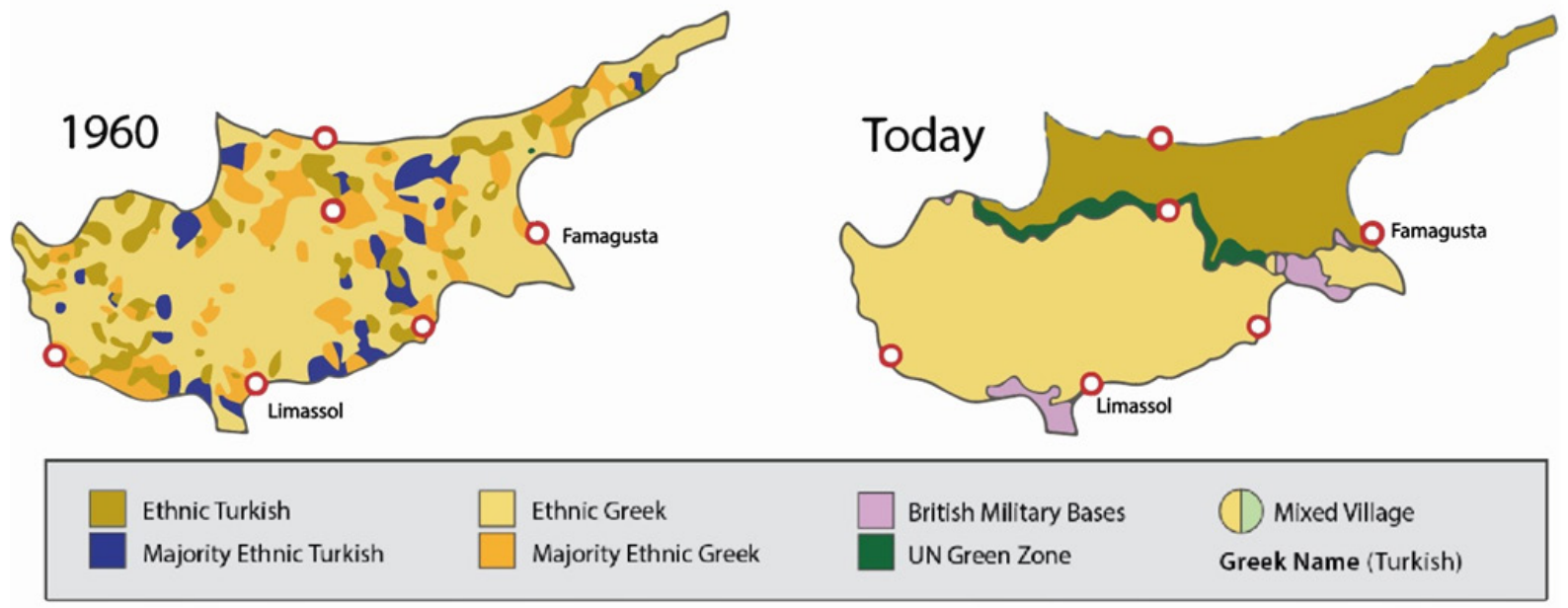

Figure 3. The island of Cyprus before and after division showing social segregation 

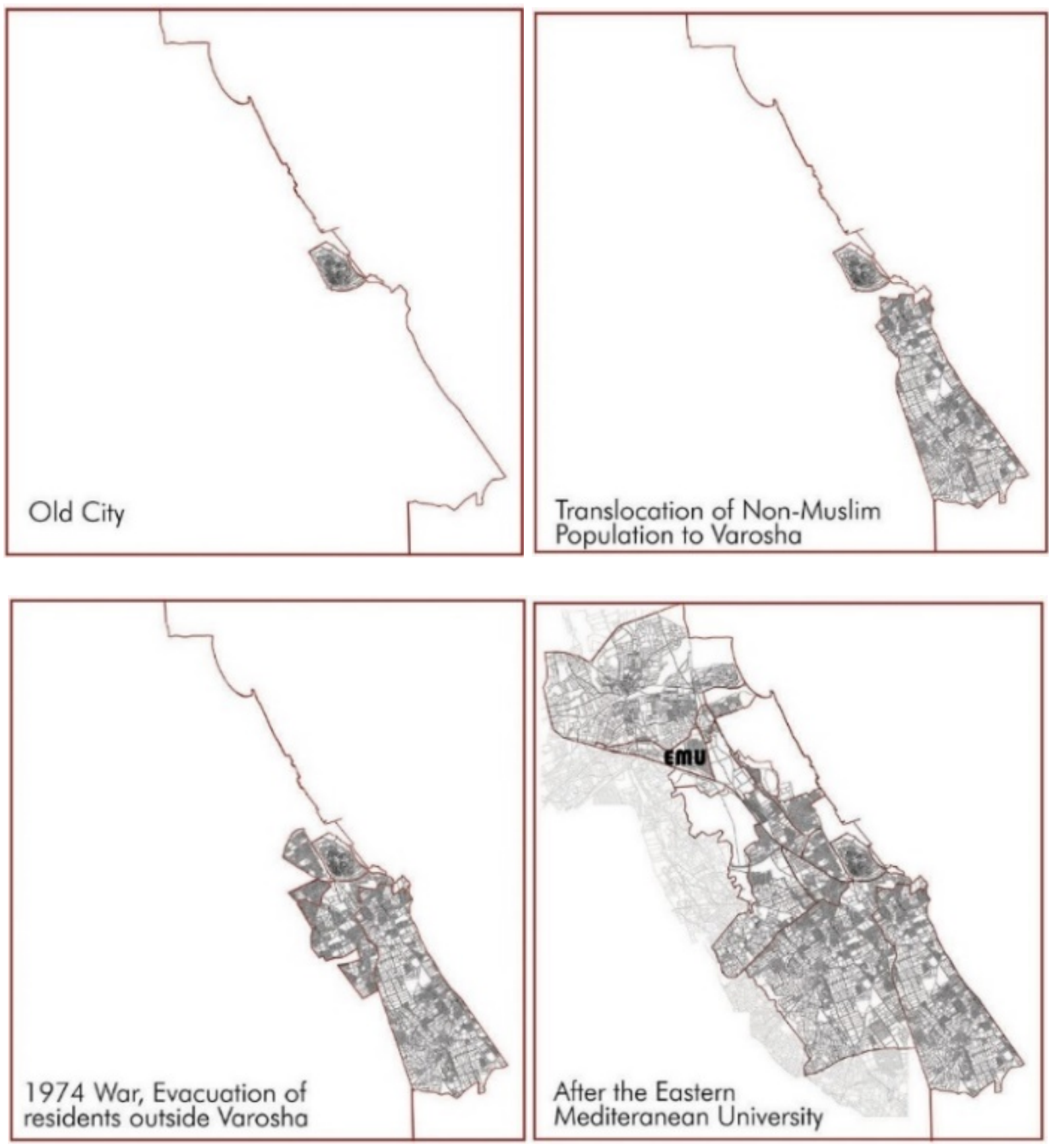

Figure 4. Urban Development of Famagusta 
Nowadays, Famagusta's economy suffers from the loss of attraction towards the port which became a marginalized priority due to the re-configuration of urban growth, this was mainly affected after the evacuation of "Verosha" city in 1974 and the closure of the coast on the western side. Further, the rapid increase of foreigners migrating after the establishment of the Eastern Mediterranean University, which today shapes one third of the overall population of the city, generated unexpected consequences [12]. The city was not prepared to this transition in social structure, thus urban patterns and population distribution were scattered with no clear vision on how to cope with the increasing demands. Subsequently, authorities developed social housing projects that also caused uncontrolled and unorganized development and more consumption of available land resources.

In regards to touristic activities, in the past those were mostly condensed in the old city, because of the port and its identity as a historical core, and Varosha being the most attractive place along the Mediterranean Sea. However, in the current situation, the cultural and historical based-tourism shifted into educational tourism, mostly located around the university $[13,14]$.

In 1967, the old port had a major impact on urban development in Famagusta, which resulted in the fusion of the old city, and the formation of the rest of the city. On the contrary, the waterfront was affected by the new developments. The socio-economic prosperity owed to the Eastern Mediterranean University, has had a major impact on the development of new areas along the coast, and on the form and overall direction of these developments.

Likewise, Beirut city on the opposite bank of the Mediterranean suffered from similar socio-political concerns. In 1920, the demographics of Beirut were boosted by the massive number of refugees displaced from different areas. Christian communities of Turkish and Armenians migrated into Beirut, followed by Syrians, Kurdish and Palestinians after the Israel-Arab war in 1967. Following that, around one million people relocated from rural areas to Beirut suburbs, and accordingly, about $50 \%$ of the overall population of Lebanon was living in Beirut in 1975. All of Lebanese and Non-Lebanese migrants lived in settlements on the outskirts of Beirut.

In spring 1975, Beirut witnessed the division between East and West. The Old Damascus Road demarcated the limits between Beirut's two new parts. It became known as the 'green line' or the 'demarcation line'. The zone was a buffer land during the cold war and a confrontation line during heated episodes. Downtown was also one of the main challenges, as almost all buildings were demolished, and serious damage along the demarcation line was assessed at $80 \%$.

Beirut came out of the war period in 1990 naked; a total disaster and a total desolation. The reconstruction proposals were mainly oriented to restore the characteristics of the Mediterranean city. The main idea was included restorations of commercial strips and to open up the city to the waterfront, whilst the other side of the project was to give a modern character to the city; it contained community buildings that symbolize the unity of the country [15].

In the post war era, Beirut began instantly to recover. All demolitions, repairs, re-buildings were launched. The government at the time was establishing the Solider Company, and it started to execute some of the main elements of the transformation of Beirut's downtown; renovation and recreation of much of the built fabric in the historic sectors. The demolition of the area of high symbolic significance demanded essential renovations, especially for the downtown which is the heart of Beirut.

The CDB was expected to provide a concrete way out of the social crisis, the reconstruction of the downtown area was expected to revitalize the economic situation of the city, especially after the war, through adding a modern character to the historical context which was in need of transformation [16].

Beirut was strongly affected after the war and the way the reconstructions were contrived had negative side in the long term. It is clearly shown how the regeneration plan did not tackle the social segregation as there are some clear places still segregated for Muslims-Shi'a only, Muslim-Sunni only and Christians only.

\section{Discussion and Conclusions: The Mediterranean Conceptualized}

The purpose of the study is to deepen the perspective on the physical transformation of Mediterranean territories in general and cities in particular which are associated with external trends, such as migration, post-colonization affects, social changes, economic and political activities. The Successive urban typologies of cities are in fact a direct response to the emergence and constant changes of socio-economic and geo-political conditions of the whole region. These changes were reflected on land-use, social classes distribution, economic indicators, political conflicts, and often result in unplanned sprawl.

As a result, this study emphasises that economic growth of ports is directly related to the evolution of cities around water bodies. The linkage between ports and coastline has ever been crucial in the evolution of Mediterranean coastal cities. The function of ports and their economic statuses affect the coastline and hence the growth, land values, and shape of the city as a whole.

It is evident that tourists flow usually occurs around focal points of the city; therefore, historical and cultural tourism is not anymore the driver of tourism-based economy, such as in the case of the university in Famagusta. These focal emerging elements represent a new form of touristic attraction. Thus, in the 
Mediterranean region circumstances, the study finds out that any new development might re-shape the fabric of the city in different forms. It is clearly noticeable how the coastline has lost its significance in the last century. Therefore, in order for cities to revive their significance, it is important to recover the role of coasts as the prime element and core of development, instead of investing coastal resources on touristic attractions which does not provide a long term strategic and comprehensible economical vision, rather, it mainly concerns with seasonal income, which might change due to diverse circumstances. Bearing this in mind, coastal cities are required to revive back their importance; implying that all the unused areas along the coast should repossess their valuable attractiveness. The study suggests that the unused brownfields should recover their role as the core of any future development. Nonetheless, in order to prevent further negative sprawl implied from the de-centralized planning actions, new building regulations that limit the built-up area, set-backs, and provide mixed-use functions should be set accordingly.

Cities today are represented by large number of foreigners who in fact control a large percentage of social and economic rates with students, labour, and political immigrants representing the new concept of globalization in the region. Furthermore, some regions, such as some parts of the northern Mediterranean coast that experienced no urban expansion in the last few decades, is related to the declination of its population. The reason of the declining population is due to poor economic situations.

It can be concluded that the economic situation of the coastal cities is weaker than it used to be before the 20th century, thus the urban expansion is being hindered. Although the overall population of the region is rapidly increasing, yet the declination of the population in the past decades on some cities, such as Corinth region, is declining rapidly. This means that the population is concentrated in limited areas which challenges cities in dealing with infrastructure, meeting the demands for food, water, energy consumption, and environmental concerns. These and added effects have direct impact on the physical growth of cities, as well as the overall economic and political status of the Mediterranean region as a whole.

The regional effect in terms of the economic importance of the ports and canals, and the population declination directly affected coastal lines by emerging urban fabrics that are neither coherent with the original grid of the city nor having any connection to hinterlands from one side, and the sufficient role in the sea trading activities from the other side, leaving coastlines at a critical point which raises still many critical questions. Beirut is an explicit example of the transformation of urban fabric due to the changing visions of the city (Figure 5), resulted from the internal social segregation which attracted external investments aiming for economic profit only.

The discussion shows how coastlines act as an interface between internal and external transitions of the Mediterranean region, which is in fact a rich dynamic complexity. In this context, the attitude of coastlines as a system basis of cities can find a compelling rationale as well as a cohesive meaning of recovering its major role in embracing complex external and internal relations, which result in the formation of a strong and coherent urban system to cope with constant changes of the whole region.

Urban evolution chronology shows that, while the complexity in the emerging trends in the Mediterranean region is changing every day, the old urban development' elements, such as coastlines, embrace the solution for the transformation in the post-industrial era, through reviving its role as a major hub for socio-economic and geo-political cores.

Therefore, local community institutions of coastal cities, in particular, should start having an effective hand in city planning through initiating joint regional political and economic cooperation to exploit coastal regions, particularly port areas, and involve them in planning strategies in a way that guarantees the social rights of their population, before the greater countries fully revive the exclusive territorial planning vision of the pre-industrial era, which will result in re-opening the door to colonialism, especially in the present day whereas greater countries have indeed begun to connect multi-regionally through global Geo-Economic lines, in a way that was not experienced ever before. 


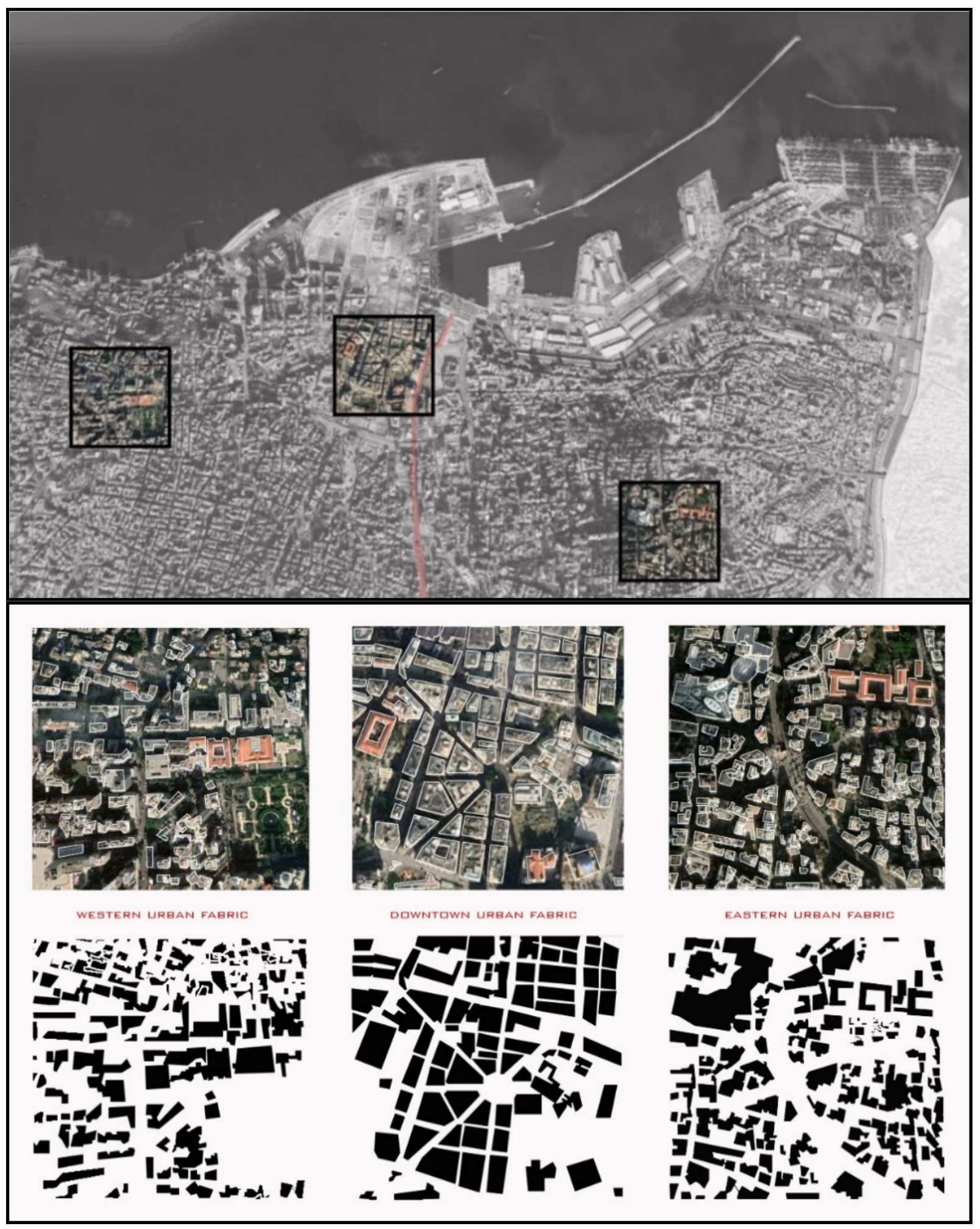

Figure 5. Different Urban Fabric present in Beirut. 


\section{Acknowledgements}

The authors would like to thank Magdi M., ElTonsi A., Ahmed Y., Magdy L., Khaled R., Hejazy S., Haroun M., Mohamed S., Bahie N., Mahmoud K., Adel H., ElMasry Y., Amin J., Magd S., Khalil R. for their support with drawings and maps throughout the study.

This research did not receive any specific grant from funding agencies in the public, commercial, or not-for-profit sectors.

\section{Conflict of Interests}

The Authors declare no conflict of interest.

\section{REFERENCES}

[1] Kolluoglu, B., \& Tokoz, M. (2010). Cities of the Mediterranean: From the Ottomans to the Present Day. New York: I.B.Tauris \& CO Ltd. ISBN: 1848851278

[2] Thorns, D. C. (2002). The Transformation of Cities. New York: Palgrave Macmillan. ISBN: 9780333745977. DOI: http://dx.doi.org/10.1007/978-1-4039-9031-0

[3] Giddens, A. (1987). Social Theory and Modern Sociology. Stanford: Stanford University Press. ISBN: 9780804713566

[4] Geddes, I. (2014). From "a miserable town of $150 \mathrm{mud}$ houses " to " the city that never sleeps " : the transformation of Limassol's urban form over the past 200 years. Our common future in Urban Morphology. Porto: 21st International Seminar on Urban form. Retrieved from https://www.researchgate.net/publication/282849727

[5] Michaelides, M., Herodotou, H., Lind, M., \& Watson, R. (2019). Port-2-Port Communication Enhancing Short Sea Shipping Performance: The Case Study of Cyprus and the Eastern Mediterranean. Sustainability.doi:10.3390/su11071 912

[6] Vaughan, L. (1988). Suburban Urbanities: Suburbs and the Life of the High Street. London: UCL Press. ISBN:
9781910634134.

DOI:http://dx.doi.org/10.2307/j.ctt1g69z0m

[7] Zazzaraa L., D’Amico F., Vrotsou M. (2012). Changing Port-City Interface at Corinth (Greece): Transformations and Opportunities, Elsevier Ltd. DOI: 10.1016/j.sbspro.201 2.06.1279

[8] Mambra, S. (2020, May 15). The Corinth Canal: A Narrow Man-Made Shipping Canal. Retrieved from https://www.marineinsight.com/: https://www.marineinsigh t.com/know-more/the-corinthian-canal-a-narrow-man-made -shipping-canal/

[9] F. Gkika, G.-A. Tselentis \& L. Danciu (2005). Seismic Risk Assessment of Corinth Canal, Greece. WIT Transactions on the Built Environment, 78, 323-332.

[10] Creel, L. (2003, September 25). Ripple Effects: Population and Coastal Regions. Retrieved April 20, 2020, from https://www.prb.org: https://www.prb.org/rippleeffectspopu lationandcoastalregions/

[11] Kostof, S. (1991). The City Shaped: Urban Patterns and Meanings Through History. Boston: Thames and Hudson. ISBN: 0821220160

[12] Katırcığlu, S. T. (2019). Investigating Higher-education-led Growth Hypothesis in a Small Island: Time Series Evidence from Northern Cyprus. (pp. 01-18). Eskişehir: Anadolu International Conference in Economics.

[13] Paul Gibbs (2002): From the invisible hand to the invisible handshake: marketing higher education, Research in Post-Compulsory Education, 7:3, 325-338. http://dx.doi.org $/ 10.1080 / 13596740200200134$

[14] Atun, R. A., Nafa, H., \& Türker, Ö. O. (2018). Envisaging sustainable rural development. Environment, Development and Sustainability.doi:https://doi.org/10.1007/s10668-018-0 $100-8$

[15] Nasr, J., \& Verdeil, É. (2008). The reconstructions of Beirut. In S. Jayyusi, A. Raymond, R. Holod, \& A. Petruccioli, The City in the Islamic World (pp. 1121-1148). Leiden: Brill. doi:https://doi.org/10.1163/ej.9789004162402.i-1500.299

[16] Al-Hagla, K. S. (2008). New Urbanism: Revitalizing historic city centers, Beirut Case. CSAAR. https://www.researchgat e.net/publication/275044415_New_Urbanism_Revitalizing historic_city_centers_Beirut_case 